\title{
Induced resistance to infection of lobsters Homarus americanus by Aerococcus viridans (var.) homari, the bacterium causing gaffkemia
}

\author{
James E. Stewart*, B. Arie, L. J. Marks \\ Science Branch, Department of Fisheries and Oceans, Bedford Institute of Oceanography, PO Box 1006, Dartmouth, \\ Nova Scotia B2Y 4A2, Canada
}

\begin{abstract}
A vaccine composed of steam sterilized (autoclaved) cells of a virulent strain of Aerococcus viridans (var.) homari was effective in protecting lobsters Homarus americanus against gaffkemia. At $15^{\circ} \mathrm{C}$ the heat-killed vaccines (HKV) at concentrations between 1 and $5 \times 10^{7}$ particles $\mathrm{kg}^{-1}$ lobster body wt induced maximal protection in induction periods ranging from 7 to $11 \mathrm{~d}$. Protection was substantial over the course of a $30 \mathrm{~d}$ post-induction trial period. Spring-caught lobsters (i.e. those more fully rehabilitated following ecdysis) gained more protection $\left(\mathrm{LD}_{50}=1.9 \times 10^{4}\right)$ from the vaccination than did those caught in the late fall-early winter period (lobsters that were not yet fully recovered from ecdysis) $\left(\mathrm{LD}_{50}=3.2 \times 10^{3}\right)$. The protection offered by the HK vaccine was comparable to that induced by a vaccine produced by incubating the pathogen with low concentrations $(2 \mu \mathrm{g}$ $\mathrm{ml}^{-1}$ ) of the antibiotic vancomycin. The bacterins produced by both methods exhibited similar new properties: (1) agglutination at low titres by lobster hemolymph serum, suggesting an impaired capsule layer, and (2) increased permeability to the large Alcian Blue molecule. With both vaccines, the protection may be a direct result of increased exposure to intact bacterial cell structures by the lobster defences, an exposure which otherwise would be prevented by an intact capsule.
\end{abstract}

KEY WORDS: Lobsters · Homarus americanus · Aerococcus viridans (var.) homari · Gaffkemia · Vaccine $\cdot$ Induced resistance

Resale or republication not permitted without written consent of the publisher

\section{INTRODUCTION}

Homarus americanus and $H$. gammarus comprise the homarid lobster industry which is based largely on trade in living animals; consequently, threats to their well-being during periods of captivity (days to months) are extremely important. In particular, these lobster species are highly susceptible to the freeliving, Gram-positive, tetrad-forming coccus Aerococcus viridans (var.) homari (previously Gaffkya homari), which causes the overwhelming systemic infection gaffkemia. Reviews of this disease include those by Stewart \& Rabin (1970), Fisher et al. (1978), Sparks (1981), Stewart (1984, 1993), Sindermann \& Lightner (1988), Sindermann (1990) among others.

The pathogen Aerococcus viridans (var.) homari is not invasive. Furthermore it is not transmitted orally as the lobster gastric fluid is lethal for the pathogen. Infection occurs only when the otherwise highly effective integument is breached in the presence of this bacterium (Stewart et al. 1969). Thus, protection against infection can be achieved through careful handling of the lobsters. Unfortunately, ordinary commercial practices cause many breaks and ruptures in the shell, thereby creating portals of entry. Upon entry, the pathogen can overcome all of the lobster's normal internal defences. Thus infection by a virulent strain of the pathogen invariably results in death of the animal. Epizootics occur periodically in holding units, resulting in serious economic losses within the industry.

Investigation of the efficacy of various antibiotics in overcoming infections showed that vancomycin was the most effective, but even then, only when administered in the very early stages of the infection (Stewart 
\& Arie 1974). This study indicated that a combination of vancomycin and moderate numbers of live pathogen in vivo might induce a degree of resistance above that provided by the antibiotic alone. Further investigation showed that such a combination was effective in inducing a high level of resistance to Aerococcus viridans (var.) homari (Stewart \& Zwicker 1974a). Subsequent studies by Rittenburg (1981) illustrated that it was possible to approach these resistance levels in lobsters by utilizing a vaccine in which the pathogen had been exposed to vancomycin in vitro and then killed by ultraviolet irradiation or formolization prior to injection of the vaccine. Later, Keith et al. (1992) reported a significant, but lower, level of protection against $A$. viridans (var.) homari induced by a formalin-killed vaccine prepared without the use of vancomycin. Given the nature of the vancomycin interaction with bacteria, Stewart \& Zwicker (1974a) and Rittenburg (1981) speculated that the combination of vancomycin with bacterial cell wall components during their formation resulted in the accumulation of precursor mucopeptides that might act as immunogen(s) effective in inducing the resistance to the pathogen.

The present study was conducted in an attempt to induce in the lobster Homarus americanus a level of protection against Aerococcus viridans (var.) homari comparable to that achieved by a combination of vancomycin and the pathogen, but without using vancomycin. We also wanted to acquire information on the nature of the immunogen(s) involved.

A wide variety of vaccines were prepared and injected into lobsters to attempt to protect them against standard challenges with the pathogen. Some vaccines were based upon the belief that the effectiveness of the vancomycin/pathogen combinations resulted from blocking the formation of wall-bound peptidoglycans and hence led to a build-up of precursor mucopeptides. Other vaccines involved different methods of preparing the bacterin.

\section{MATERIALS AND METHODS}

Lobsters. Freshly captured lobsters of both sexes (average wt $500 \pm 25 \mathrm{~g}$ ) caught in late fall-early winter and in the spring were obtained directly from fishermen in Nova Scotia, Canada. The chelae were immobilized with heavy rubber bands and the lobsters were held in tanks supplied with running, filtered seawater at ambient temperatures ranging from 1 to $12^{\circ} \mathrm{C}$ depending upon season. All experimental work was carried out in tanks of re-circulating, filtered seawater at $15 \pm 0.5^{\circ} \mathrm{C}$ after the lobsters had been acclimated to this temperature for around $2 \mathrm{wk}$, the lobsters were fed prior to, but not during, the actual challenge trials.
Individual shelters were provided in all tanks to protect the lobsters during holding periods and experimental work. Prior to the initiation of the experiments, all lobsters involved were examined by culture methods and hemolymph smears (Stewart et al. 1966) and/or an indirect fluorescent antibody technique specific for Aerococcus viridans (var.) homari (Marks et al. 1992) to ensure that they were not already infected with $A$. viridans (var.) homari.

Aerococcus viridans (var.) homari. The strain of this bacterium used throughout the study was donated by Dr. H. Rabin, Department of Pathobiology, The John Hopkins University, Baltimore, MD, USA. Its virulence was maintained by serial passage through lobsters held at $15^{\circ} \mathrm{C}$ (Cornick \& Stewart 1968). For experimental infection purposes, $0.2 \mathrm{ml}$ of hemolymph were removed from a lobster infected with Rabin's strain and transferred to $50 \mathrm{ml}$ trypticase soy broth (TSB) (Baltimore Biological Laboratories). It was grown at $28^{\circ} \mathrm{C}$ in static cultures for 18 to $24 \mathrm{~h}$, harvested and washed 3 times with sterile $3 \% \mathrm{NaCl}$ solution and standardized to different concentrations at $420 \mathrm{~nm}_{\text {; the }}$ number of colony forming units (CFU) were confirmed using trypticase soy agar (TSA) with the drop plate count method of Miles \& Misra (1938).

Vaccines. Preparation of trial vaccines included growth of the pathogen with concentrations of up to $2 \%$ glycine in attempts to capitalize on the findings of Hammes (1978) to produce a pool of precursor mucopeptides. Treatment of cells in various ways included (1) formolization and (2) cells extracted with $2 \%$ sodium dodecyl sulphate and then dialysed against $3 \% \mathrm{NaCl}$, lyophilized and used later as a vaccine. A French Press treatment was also used in which a bacterial suspension $\left(2 \times 10^{7}\right.$ bacteria $\mathrm{ml}^{-1}$ washed twice with $3 \% \mathrm{NaCl}$ ) was subjected to 2 passes in a French Press (one at 27000 and the other at 34000 psi); the resultant material was divided by centrifugation into a supernatant solution and a precipitate. Both the supernatant solution and precipitate were used as vaccines after being returned to the volume of the original suspension. The resuspended precipitate and the supernatant solution were injected after being dialysed against $3 \% \mathrm{NaCl}_{i}$ in a second experiment the set was injected without being dialysed.

Heat-killed vaccine (HKV). Eighteen to $24 \mathrm{~h}$ TSB cultures of Aerococcus viridans (var.) homari with its virulence maintained as described above were harvested by centrifugation $\left(25000 \times g\right.$ for $10 \mathrm{~min}$ at $\left.4^{\circ} \mathrm{C}\right)$, washed twice with $3 \% \mathrm{NaCl}$ solution and standardized at $420 \mathrm{~nm}$ in a $3 \%$ saline suspension containing for most trials approximately $2 \times 10^{7}$ cells ml ${ }^{-1}$; the number of CFU was confirmed by TSA plate counts. The suspension was steam sterilized in a standard autoclave $\left(121^{\circ} \mathrm{C}\right.$ at $15 \mathrm{psi}$ for $\left.15 \mathrm{~min}\right)$; the sterility of the cooled 
suspension was confirmed in triplicate by lack of growth in TSB. The entire sterile bacterial suspension was used for vaccination by injecting $1 \mathrm{ml}$ vaccine $\mathrm{kg}^{-1}$ lobster body weight (wt) via the ventral abdominal sinus. Parallel sets of control lobsters were injected with $1 \mathrm{ml} \mathrm{kg}^{-1}$ body wt of a sterile $3 \% \mathrm{NaCl}$ solution instead of the vaccine and exposed to the same conditions as the experimental animals for the full period of the trial. The external surfaces of the injection area were swabbed with $70 \%$ ethanol before and after injection.

Challenges. For challenges of groups of lobsters, each group was held in a separate tank. The bacteria were injected into the ventral abdominal sinus of individual lobsters and the lobsters were examined several times daily. Lobsters that died in these trials were removed and examined by hemolymph smears and/or culture methods to determine the cause of death. Only dead lobsters shown to be heavily infected with the pathogen were used to calculate the mean time to death (MTD) in days.

Capsules. Slides made from bacterial cultures prepared using standard blood smear procedures were air-dried, heat-fixed and stained by a procedure for polysaccharide staining adapted from McKinney (1953). Briefly, 1 g Alcian Blue 8GX (about $1300 \mathrm{~mol}$ wt) (Sigma Aldrich Canada) in $100 \mathrm{ml} \mathrm{95 \%} \mathrm{ethanol}$ was used as the stock solution. Just prior to staining, 1 part Alcian Blue stock solution was added to 9 parts distilled water and applied to the slide for 2 min and then washed off with distilled water. The slides were then counterstained for $25 \mathrm{~s}$ with $1 \%$ aqueous neutral red, washed with distilled water, blotted dry with bibulous paper, air-dried for $30 \mathrm{~min}$ and then examined microscopically using an oil immersion objective (magnification $\times 1000$ ). The bacteria growing normally in TSB stained red; the surrounding capsules stained blue.

Phagocytosis. Phagocytosis by lobster hemocytes was determined using the protocols as described by Paterson \& Stewart (1974) using glutaraldehyde/ formalin fixed preparations. Total hemocyte numbers were determined electronically for individual lobsters using a particle counter (Model B, Coulter Electronics) following the procedure of Stewart et al. (1967).

Sterile lobster hemolymph serum. Based on the procedure of Lauffer \& Swaby (1955), hemolymph drawn from the ventral abdominal sinus was allowed to form a non-retracting, firm, hard clot. The clot was broken up with a stirring rod and centrifuged at $2000 \times g$ for $20 \mathrm{~min}$; the supernatant fluid was passed through coarse filter paper at $5^{\circ} \mathrm{C}$ and then sterilized by membrane filtration $(0.22 \mu \mathrm{m}$ pore size $)$ and stored at $4^{\circ} \mathrm{C}$ for use within $7 \mathrm{~d}$ for agglutination trials (Cornick \& Stewart 1968, 1973). For use in the phagocytosis study, the fluid was filtered through a $0.45 \mu \mathrm{m}$ pore size membrane filter and frozen.

Agglutination. Standard tube agglutination tests employing serial 2-fold dilutions were performed with freshly prepared lobster hemolymph serum. Rabin's strain of Aerococcus viridans (var.) homari grown at $28^{\circ} \mathrm{C}$ in TSB as specified was harvested and washed twice with $3 \% \mathrm{NaCl}$ solution using centrifugation at $15000 \times g$ at $4{ }^{\circ} \mathrm{C}$ and suspended in $3 \% \mathrm{NaCl}$ to correspond with the McFarland turbidity scale 2 (Kabat \& Mayer 1961). The tubes were incubated at $25^{\circ} \mathrm{C}$ for $24 \mathrm{~h}$ to determine the titre. Agglutination titres are reported as reciprocals of the dilutions.

Experiments. As initial tests using the heat-killed vaccine and a post-vaccination induction period of $7 \mathrm{~d}$ (Stewart \& Zwicker (1974a) showed promise, a further series of trials was conducted. The HKV was tested in detail in challenges to measure its capacity to protect against the pathogen Aerococcus viridans (var.) homari in late fall-winter caught lobsters (lobsters not yet fully recovered from ecdysis) versus spring-caught lobsters (i.e. lobsters with shells of maximum hardness, fully muscled and with higher concentrations of hemolymph constituents such as proteins and hemocytes among others). This was followed by trials to determine what changes in protection might occur during a $30 \mathrm{~d}$ post-vaccination period. In addition, trials were run to determine the concentration of bacterial particles in the vaccines that gave the best results.

Subsequent to these trials, 16 lobsters were used to determine whether resistance to infection induced by the HKV was paralleled by increases in the phagocytic capacity of the circulating hemocytes. Phagocytosis of virulent Aerococcus viridans (var.) homari cells by hemocytes of 8 vaccinated lobsters (given an HKV of $2 \times 10^{7}$ bacterial particles $\mathrm{ml}^{-1}$ ) was compared with that exhibited by hemocytes from 8 control lobsters injected with a sterile $3 \% \mathrm{NaCl}$ solution at the same amount ( $1 \mathrm{ml} \mathrm{kg}^{-1}$ host body wt). These sets of measurements were made on 4 lobsters per sampling time, thereby alternating with the other 4 lobsters in the group to minimize the stress of handling. These measurements were made at 5 sampling times in the pre-challenge period and 3 sampling times in the postchallenge period.

As a final step, suspensions of bacterial particles from the HKV preparation, a vaccine prepared following Rittenburg's (1981) procedure (i.e. growth of the pathogen in TSB in the presence of vancomycin) and an untreated TSB pathogen culture were subjected to capsule staining and agglutination by lobster hemolymph serum. All 3 of these bacterial or bacterial particle suspensions were prepared from TSB cultures initiated by subculture from the same culture of Aerococcus viridans (var.) homari; all grown at $28^{\circ} \mathrm{C}$. The 
HKV was prepared from the $18 \mathrm{~h}$ culture as described earlier. The Rittenburg vaccine version was produced following the procedure of Rittenburg (1981) i.e. by tracking the turbidity produced by the pathogen growing in $\mathrm{TSB}_{\text {; }}$ at the point where it just became visible, a growth inhibiting dose of $1 \mathrm{ml}$ of an $84 \mathrm{\mu g} \mathrm{ml}^{-1}$ vancomycin hydrochloride hydrate (Aldrich) in distilled water was added to each of the $40 \mathrm{ml}$ TSB culture flasks and incubation was continued for another $12 \mathrm{~h}$.

All 3 cultures were harvested at the $18 \mathrm{~h}$ growth period by centrifugation $\left(28000 \times g\right.$ for $10 \mathrm{~min}$ at $\left.4^{\circ} \mathrm{C}\right)$ washed twice with $3 \% \mathrm{NaCl}$ and resuspended in $3 \%$ $\mathrm{NaCl}$ at 0.7 optical density (1 cm light path; $550 \mathrm{~nm}$ ). The suspensions intended for the HKV were then run through a standard autoclave cycle, i.e. $121^{\circ} \mathrm{C}$ at 15 psi for $15 \mathrm{~min}$. All 3 suspensions were then stained using the capsule stain of McKinney (1953) and the agglutination titres were measured in quadruplicate against 2 different preparations of lobster hemolymph serum.

\section{RESULTS}

As the data in Table 1 indicate, the HKV was effective in protecting 70 to $80 \%$ of the vaccinated lobsters challenged after a $7 \mathrm{~d}$ induction period and $60 \%$ of the survivors from Group A were still resistant $26 \mathrm{~d}$ after the first challenge as shown by exposure to a second challenge.

When this initial trial was followed by a titration challenge ranging from $2 \times 10^{2}$ to $2 \times 10^{5}$ pathogen $\mathrm{kg}^{-1}$ body wt using late fall-winter caught lobsters (Table 2) and an identical challenge against spring caught lobsters (Table 3 ), the results suggested that the spring caught lobsters developed a higher degree of resistance. This protection against a challenge of $2 \times 10^{3}$ persisted at the 60 to $70 \%$ relative percent survival (RPS) level for up to $30 \mathrm{~d}$ post-vaccination, peaking apparently around $11 \mathrm{~d}$ following vaccination, as shown in Table 4. Although the differences are not great it would appear from the results in Table 1 and Table 5 that more protection is offered by the higher vaccine concentrations, with values between 2 and $5 \times$ $10^{7}$ particles $\mathrm{kg}^{-1}$ body wt being most effective.

Table 6 indicates that the phagocytic capacity of circulating hemocytes did increase in parallel with the resistance to the infection. The post-challenged lobsters exhibited the greatest increase in the significant percentage of hemocytes showing phagocytosis, to an average value of $1.23 \%$ for all 8 vaccinated lobsters $(p<0.01)$. As hemocytes of only 3 of the 8 vaccinated lobsters showed an increase, this value would exceed $3 \%$ of the hemocytes in the 3 lobsters showing increased phagocytosis and also increased resistance to infection. This represents a greater than 6-fold increase in the number of hemocytes showing increased phagocytic capacity compared with the values for the post-challenged unvaccinated lobsters. Rittenburg (1981) also observed a substantial increase in phagocytic capacity of the hemocytes among lobsters receiving his vaccine

The capsule staining showed that the washed, but otherwise untreated, bacteria exhibited the expected characteristics; the cells in tetrads, pairs and singles stained red and the substantial surrounding capsule

Table 1. Initial trials with heat-killed Aerococcus viridans (var.) homari vaccine. MTD: mean time to death

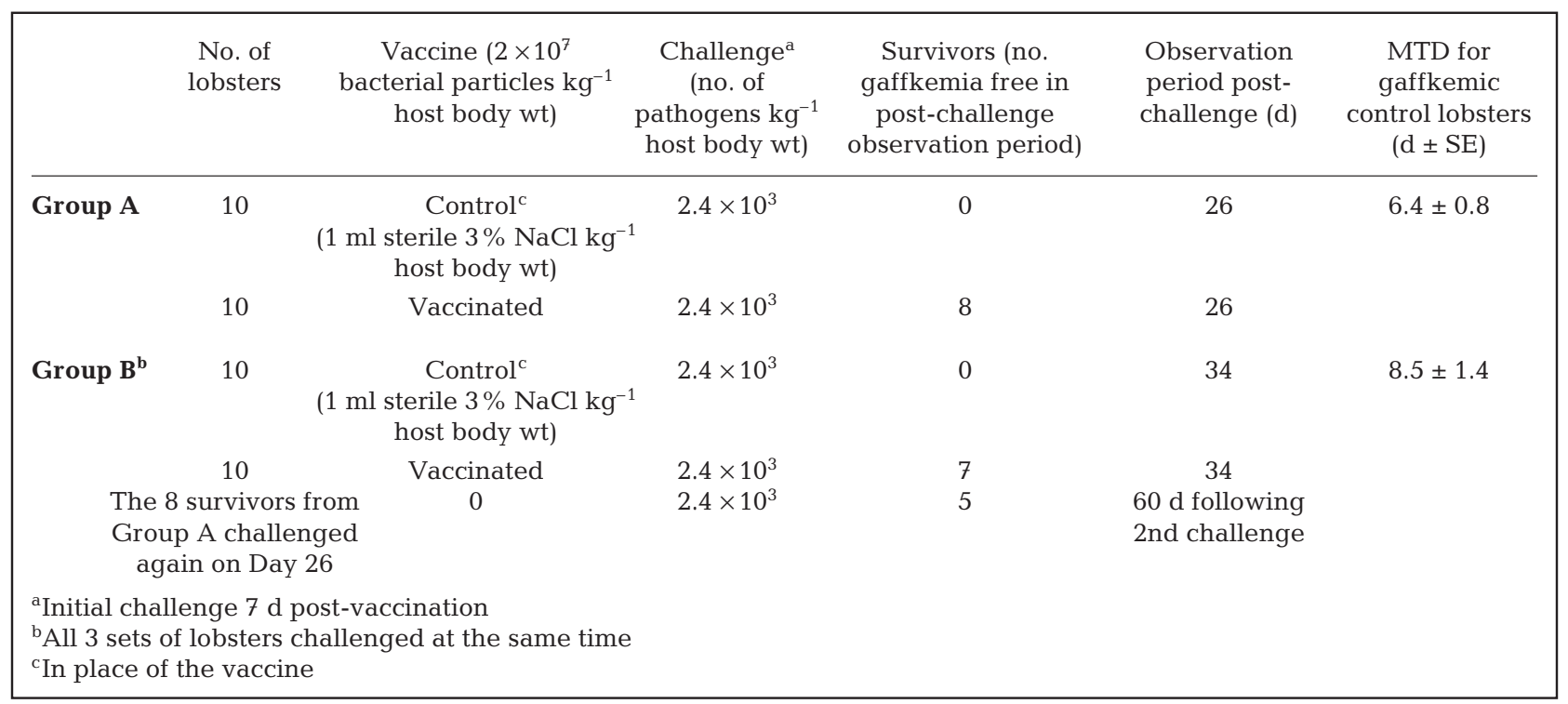


stained blue, with the intervening material in the tetrad staining blue to bluish green. In contrast, the bacteria grown in the presence of vancomycin presented a blotchy appearance, i.e. the capsular zones surrounding the bacteria were ragged, but stained blue as did portions of the bacterial bodies. Some irregular portions of the bacterial bodies stained dark blue and other portions were stained red. The bacterial particles from the HKV carried this alteration in staining a step further. The morphology of tetrads, pairs and singles remained the same. However, the capsules could not be distinguished since the entire cell, including the capsule and bacterial body, was stained dark blue throughout. Even prolonged treatment with the counter-stain, neutral red, did not result in staining any part of the cell red. When only neutral red was applied, the cells took up the red stain. Obviously, a major change in the permeability of the bacterial cells occurred when they were grown in the presence of vancomycin and more so when the suspensions of normal growth cells were autoclaved.

That the bacteria were changed by these treatments was confirmed by the agglutination tests. The untreated or normal Aerococcus viridans (var.) homari suspensions showed no agglutination reaction in 2 separate quadruplicate trials with 2 separate lobster sera; in the same trials, the vancomycin-treated pathogen had an agglutination titre of 8 while in one quadruplicate trial the autoclaved or HKV cells gave titres of 2 and in the other trial a titre of 4 .

Table 2. Sixty day trials with heat-killed vaccine on lobsters caught in late fall-winter. Calculated $\mathrm{LD}_{50}: 3.2 \times 10^{3}$

\begin{tabular}{|c|c|c|c|c|}
\hline $\begin{array}{l}\text { No. of } \\
\text { lobsters }\end{array}$ & $\begin{array}{l}\text { Vaccine }\left(2 \times 10^{7}\right. \\
\text { bacterial particles } \mathrm{kg}^{-1} \\
\text { host body wt })\end{array}$ & $\begin{array}{l}\text { Challenge (no. of pathogens } \\
\mathrm{kg}^{-1} \text { host body wt injected } \\
7 \mathrm{~d} \text { post-vaccination) }\end{array}$ & $\begin{array}{l}\text { Survivors (no. gaffkemia } \\
\text { free in post-challenge } \\
\text { observation period) }\end{array}$ & $\begin{array}{l}\text { MTD for } \\
\text { gaffkemic control } \\
\text { lobsters }(\mathrm{d} \pm \mathrm{SE})\end{array}$ \\
\hline 10 & $\begin{array}{c}\text { Control }^{\mathrm{a}} \\
\left(1 \mathrm{ml} 3 \% \text { sterile } \mathrm{NaCl} \mathrm{kg}{ }^{-1}\right. \\
\text { host body wt })\end{array}$ & $2 \times 10^{2}$ & 0 & $10.8 \pm 1.3$ \\
\hline 10 & " 1 (1) & $2 \times 10^{3}$ & 0 & $10.6 \pm 1.4$ \\
\hline 10 & $“$ & $2 \times 10^{4}$ & 0 & $10.3 \pm 1.6$ \\
\hline 10 & $"$ & $2 \times 10^{5}$ & 0 & $\begin{array}{l}10.6 \pm 1.2 \\
\operatorname{RPS}^{\mathrm{b}}\end{array}$ \\
\hline 10 & Vaccinated & $2 \times 10^{2}$ & 10 & 100 \\
\hline 10 & $"$ & $2 \times 10^{3}$ & 6 & 60 \\
\hline 10 & $"$ & $2 \times 10^{4}$ & 4 & 40 \\
\hline 10 & $"$ & $2 \times 10^{5}$ & 0 & 0 \\
\hline \multicolumn{5}{|c|}{${ }^{\mathrm{a}}$ In place of the vaccine } \\
\hline \multicolumn{5}{|c|}{${ }^{\mathrm{b}}$ Relative percent survival $=1-\left(\frac{\% \text { specific mortalities in vaccinates }}{\% \text { specific mortalities in controls }}\right) \times 100$} \\
\hline
\end{tabular}

Table 3. Sixty day trials with heat-killed vaccine on lobsters caught in spring. Calculated $\mathrm{LD}_{50}: 1.9 \times 10^{4}$

\begin{tabular}{|c|c|c|c|c|}
\hline $\begin{array}{l}\text { No. of } \\
\text { lobsters }\end{array}$ & $\begin{array}{l}\text { Vaccine }\left(2 \times 10^{7}\right. \\
\text { bacterial particles } \mathrm{kg}^{-1} \\
\text { host body wt })\end{array}$ & $\begin{array}{l}\text { Challenge (no. of pathogens } \\
\mathrm{kg}^{-1} \text { host body wt injected } \\
7 \text { d post-vaccination) }\end{array}$ & $\begin{array}{l}\text { Survivors (no. gaffkemia } \\
\text { free in post-challenge } \\
\text { observation period) }\end{array}$ & $\begin{array}{l}\text { MTD for } \\
\text { gaffkemic control } \\
\text { lobsters }(\mathrm{d} \pm \mathrm{SE})\end{array}$ \\
\hline 10 & 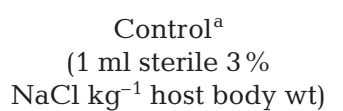 & $2 \times 10^{2}$ & 0 & $10.7 \pm 1.6$ \\
\hline 10 & 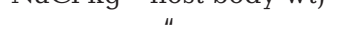 & $2 \times 10^{3}$ & 0 & $10.3 \pm 1.5$ \\
\hline 10 & $"$ & $2 \times 10^{4}$ & 0 & $8.9 \pm 1.4$ \\
\hline 10 & $"$ & $2 \times 10^{5}$ & 0 & $\begin{array}{c}8.4 \pm 1.3 \\
\text { RPS }\end{array}$ \\
\hline 10 & Vaccinated & $2 \times 10^{2}$ & 10 & 100 \\
\hline 10 & " & $2 \times 10^{3}$ & 8 & 80 \\
\hline 10 & $"$ & $2 \times 10^{4}$ & 7 & 70 \\
\hline 10 & “ & $2 \times 10^{5}$ & 0 & 0 \\
\hline
\end{tabular}


Table 4. Determination of protection in post-vaccination period of winter caught lobsters. Observation periods: Group A, $41 \mathrm{~d}$ post-challenge; Group B, 65 d post-challenge

\begin{tabular}{|c|c|c|c|c|}
\hline $\begin{array}{l}\text { Group A } \\
\text { No. of } \\
\text { lobsters }\end{array}$ & $\begin{array}{l}\text { Vaccine }\left(2 \times 10^{7}\right. \\
\text { bacterial particles } \mathrm{kg}^{-1} \\
\text { host body wt })\end{array}$ & $\begin{array}{c}\text { Challenge }^{\mathrm{b}} \\
\text { (d post-vaccination) }\end{array}$ & $\begin{array}{l}\text { Survivors (no. gaffkemia } \\
\text { free in post-challenge } \\
\text { observation period) }\end{array}$ & $\begin{array}{c}\text { MTD for } \\
\text { gaffkemic lobsters } \\
(\mathrm{d} \pm \mathrm{SE})\end{array}$ \\
\hline 10 & $\begin{array}{c}\text { Control }^{\mathrm{a}} \\
(1 \mathrm{ml} \text { sterile } 3 \% \\
\left.\mathrm{NaCl} \mathrm{kg}{ }^{-1} \text { host body wt }\right)\end{array}$ & 0 & 0 & $7.4 \pm 0.3$ \\
\hline 10 & Vaccinated & 2 & 0 & $16.6 \pm 1.3$ \\
\hline 10 & $"$ & 4 & 2 & $17.6 \pm 2.0$ \\
\hline 10 & $"$ & 6 & 4 & $14.8 \pm 1.2$ \\
\hline 10 & $"$ & 8 & 6 & $15.8 \pm 2.8$ \\
\hline $\begin{array}{l}\text { Group B } \\
\text { No. of } \\
\text { lobsters }\end{array}$ & $\begin{array}{l}\text { Vaccine }\left(5 \times 10^{7}\right. \\
\text { bacterial particles } \mathrm{kg}^{-1} \\
\text { host body wt })\end{array}$ & $\begin{array}{c}\text { Challenge }^{\mathrm{b}} \\
\text { (d post-vaccination) }\end{array}$ & $\begin{array}{l}\text { Survivors (no. gaffkemia } \\
\text { free in post-challenge } \\
\text { observation period) }\end{array}$ & $\begin{array}{l}\text { MTD for } \\
\text { gaffkemic lobsters } \\
(\mathrm{d} \pm \mathrm{SE})\end{array}$ \\
\hline 10 & 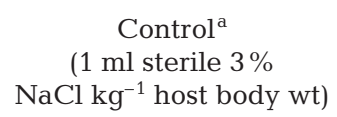 & 14 & 0 & $9.4 \pm 1.7$ \\
\hline 10 & Vaccinated & 9 & 5 & $12.6 \pm 3.7$ \\
\hline 10 & $"$ & 11 & 9 & \\
\hline 10 & $"$ & 13 & 7 & $21 \pm 4.0$ \\
\hline 10 & $"$ & 20 & 5 & $25.4 \pm 4.8$ \\
\hline 10 & $"$ & 30 & 6 & $15 \pm 3.7$ \\
\hline
\end{tabular}

Table 5. Effect on protection of varying particle numbers with heat-killed vaccines on winter caught lobsters. Observation period: $34 \mathrm{~d}$ post-challenge

\begin{tabular}{|c|c|c|c|c|}
\hline $\begin{array}{l}\text { No. of } \\
\text { lobsters }\end{array}$ & $\begin{array}{l}\text { Vaccine (no. of } \\
\text { bacteria particles } \mathrm{kg}^{-1} \\
\text { host body wt) }\end{array}$ & $\begin{array}{l}\text { Challenge }\left(2 \times 10^{3} \text { pathogen }\right. \\
\mathrm{kg}^{-1} \text { host body wt } \\
\text { injected } 7 \mathrm{~d} \text { post-vaccination })\end{array}$ & $\begin{array}{l}\text { Survivors (no. gaffkemia } \\
\text { free in post-challenge } \\
\text { observation period) }\end{array}$ & $\begin{array}{c}\text { MTD for } \\
\text { gaffkemic lobsters } \\
(\mathrm{d} \pm \mathrm{SE})\end{array}$ \\
\hline 10 & $\begin{array}{c}\text { Control }^{\mathrm{a}} \\
(1 \mathrm{ml} \text { sterile } 3 \% \\
\left.\mathrm{NaCl} \mathrm{kg}{ }^{-1} \text { host body wt }\right)\end{array}$ & + & 0 & $9.3 \pm 1.3$ \\
\hline & Vaccinated & & & \\
\hline 10 & $1 \times 10^{6}$ & + & 3 & $14.3 \pm 2.3$ \\
\hline 10 & $5 \times 10^{6}$ & + & 2 & $19.3 \pm 1.4$ \\
\hline 10 & $1 \times 10^{7}$ & + & 4 & $20.9 \pm 2.5$ \\
\hline 10 & $5 \times 10^{7}$ & + & 6 & $21.1 \pm 4.0$ \\
\hline 10 & $1 \times 10^{8}$ & + & 4 & $20.4 \pm 3.2$ \\
\hline
\end{tabular}

Many of the extensive trials with the other vaccines mentioned earlier as being under examination extended the times of the MTDs and some produced RPS values of 10 to $20 \%$ and in one instance (with an in vivo grown formolized pathogen version) an RPS of $40 \%$. None of these vaccines was judged effective enough to pursue further development. The results from the French Press work, however, could be of importance in further research on the development of vaccines. The French Press preparations proved to be deleterious in that the lobsters injected with these products died one by one before completion of the $7 \mathrm{~d}$ post-vaccination induction period.

\section{DISCUSSION}

Stewart \& Zwicker (1974a) showed that the American lobster developed a high degree of resistance to virulent Aerococcus viridans (var.) homari following injection with an appropriate immunogen(s). Their opinion that the range of materials inducing resistance 
Table 6. Effect of heat-killed vaccine on phagocytosis of virulent Aerococcus viridans (var.) homari cells. Average values for all lobsters measured alternately, 4 per sampling time: 5 sampling times pre-challenge: $4 \mathrm{~h}, 1,2,4$ and $7 \mathrm{~d}$ and 3 sampling times post-challenge: 1, 2 and $4 \mathrm{~d}$

\begin{tabular}{|c|c|c|c|c|c|}
\hline & $\begin{array}{c}\text { Total } \\
\text { hemocytes } \\
\left(\mathrm{mm}^{3}\right)^{-1} \pm \mathrm{SE}\end{array}$ & $\begin{array}{l}\text { Percent hemocytes } \\
\text { showing } \\
\text { phagocytosis }^{\mathrm{a}} \pm \mathrm{SE}\end{array}$ & $\begin{array}{l}\text { Lobsters number } \\
\text { showing increased } \\
\text { phagocytosis }\end{array}$ & $\begin{array}{l}\text { Lobsters number } \\
\text { surviving }>60 \mathrm{~d} \\
\text { post-challenge }^{\mathrm{b}}\end{array}$ & $\begin{array}{c}\text { MTD for } \\
\text { non-survivors } \\
(d \pm S E)\end{array}$ \\
\hline \multicolumn{6}{|c|}{8 control lobsters } \\
\hline Pre-challenge & $20606 \pm 417$ & $0.21 \pm 0.04$ & 0 & - & - \\
\hline Post-challenge & $18824 \pm 267$ & $0.47 \pm 0.05$ & $0 / 8$ & $0 / 8$ & $9.1 \pm 2.1$ \\
\hline \multicolumn{6}{|c|}{8 vaccinated lobsters } \\
\hline Pre-challenge & $23347 \pm 253$ & $0.58 \pm 0.05$ & $3 / 8$ & - & - \\
\hline Post-challenge & $18200 \pm 209$ & $1.23 \pm 0.09$ & $3 / 8$ & $3 / 8$ & $18.2 \pm 10.2$ \\
\hline
\end{tabular}

or a form of immunity in lobsters is probably quite limited tends to be confirmed by the investigations of Rittenburg (1981), and Keith et al. (1992) as well as with the results presented in this paper.

Our results illustrate that the immunogen(s), produced by steam sterilization of the late log phase cells of Aerococcus viridans (var.) homari, produce a high degree of protection, ranging from an $\mathrm{LD}_{50}$ of $3.2 \times 10^{3}$ to $1.9 \times 10^{4}$, comparable to that induced by the vaccine reported by Rittenburg (1981). The advantage of the steam sterilized vaccine or HKV includes its simplicity of preparation and elimination of vancomycin to produce an effective immunogen either in vivo (Stewart \& Zwicker 1974a) or during in vitro growth (Rittenburg 1981). Neither the HKV nor the Rittenburg (1981) vaccine, however, appear to be as effective as the immunogen(s) produced in vivo by the vancomycinlive pathogen combination, which resulted in an $\mathrm{LD}_{50}$ of $2 \times 10^{7}$ live pathogen $\mathrm{kg}^{-1}$ body wt (Stewart \& Zwicker 1974a).

It would appear that the original speculation by Stewart \& Zwicker (1974a) and Rittenburg (1981) that the immunogen(s) were a result of the interference of the formation of wall-bound peptidoglycans by the antibiotic vancomycin was incorrect. Additional evidence for this includes our failure to produce an effective vaccine by using $2 \%$ glycine as a substitute for vancomycin in the late log phase of growth to block wallbound peptidoglycan formation in the pathogen and produce a pool of precursor mucopeptides (Hammes 1978); the vaccines produced in this manner were not successful in inducing resistance. These results, along with those of Keith et al. (1992), suggest that the required immunogen(s) apparently are inherent elements of normal Aerococcus viridans (var.) homari.

The similarities between the HKV and the vaccine prepared by Rittenburg (1981) included virtually iden- tical levels of protection and increased phagocytosis, an element that is probably an integral part of the development of resistance to infection. More critically, the procedures used to prepare the 2 vaccines also resulted in turning previously virulent agglutininresistant strains into products that were agglutinated by lobster hemolymph serum; the agglutination titre was somewhat higher against the Rittenburg vaccine than it was for the HKV.

Stewart (1984) and Stewart et al. (2004) showed a correlation between encapsulation and virulence. Apparently, the presence of a complete capsule prevents the agglutination of the virulent strain. Thus it would appear that for a vaccine to be successful it should have the capsule altered in such a manner that the lobster hemolymph factors are not blocked from reacting to a significant extent with immunogen(s) in the bacterial body.

The capsule staining reactions of the bacterial particles in the 2 vaccines, although somewhat different, along with the agglutination results indicate that the capsular layer has been altered and that a major change has occurred in cell permeability. The Alcian Blue molecule is large (about $1300 \mathrm{~mol} \mathrm{wt}$ ) and is excluded by untreated normal bacterial cells; upon growth in the presence of vancomycin or upon steam sterilization the permeability of the bacterial cell was altered sufficiently to permit entry of this dye. These data suggest that the immunogen(s) could be intact bacterial cell walls or possibly other constituents of the cells now exposed by treatment with vancomycin or heat.

The results here and in those reported by Keith et al. (1992) also suggest that the concentration of the appropriate immunogen(s) is a critical factor in developing the varying degrees of resistance to infection. The deleterious effects of the cell fragments and soluble cell constituents released by French Press treatment 
add weight to the suggestion that the immunogen(s) are part of intact bacterial cells.

The presence of a well-developed intact capsule has been shown to be a feature in determining the virulence of this pathogen (Stewart 1984, Stewart et al. 2004). As our current results suggest that impairment of the capsule was necessary for the effectiveness of the vaccine, a question arises concerning the avirulent strains of this pathogen. These lack a capsule or possess only trace amounts of the capsular polysaccharide and thus would be expected to form effective vaccines if their immunogenic formula and concentration were equivalent to that of the virulent strains. Although vaccines prepared from avirulent strains of Aerococcus viridans (var.) homari have resulted in increased resistance as indicated by extensions of the MTD, they did not offer complete protection under the conditions applied in those trials (Stewart \& Zwicker 1974b). If the information gained subsequently with virulent strains was applied to avirulent strains, i.e. comparable concentrations of the bacterial particles, with longer induction periods and lower dose challenges, would the results of those vaccinations be comparable to those gained with the HKV?

\section{LITERATURE CITED}

Cornick JW, Stewart JE (1968) Interaction of the pathogen Gaffkya homari with natural defense mechanisms of Homarus americanus. J Fish Res Board Can 25:695-709

Cornick JW, Stewart JE (1973) Partial characterization of a natural agglutinin in the hemolymph of the lobster, Homarus americanus. J Invertebr Pathol 21:255-262

Fisher WS, Nilson EH, Steenbergen JF, Lightner DV (1978) Microbial diseases of cultured lobsters: a review. Aquaculture 14:115-140

Hammes WP (1978) The LD-carboxypeptidase activity in Gaffkya homari: the target of the action of D-amino acids or glycine on the formation of wall-bound peptidoglycan. Eur J Biochem 91:501-507

Kabat EA, Mayer MM (1961) Experimental immunochemistry, 2nd edn. Thomas, Springfield, IL

Keith IR, Paterson WD, Airdrie D, Boston LD (1992) Defense mechanisms of the American lobster (Homarus americanus): vaccination provided protection against gaffkemia infections in laboratory and field trials. Fish Shellfish Immunol 2:109-119

Lauffer MA, Swaby LG (1955) The size, shape and hydration of lobster hemocyanin. Biol Bull 108:290-295

Marks LJ, Stewart JE, Håstein T (1992) Evaluation of an indirect fluorescent antibody technique for detection of Aerococcus viridans (var.) homari, pathogen of homarid lobsters. Dis Aquat Org 13:133-138

Editorial responsibility: Timothy Flegel, Bangkok, Thailand
McKinney RE (1953) Staining bacterial polysaccharides. J Bacteriol 66:453-454

Miles AA, Misra SS (1938) The estimation of the bactericidal power of the blood. J Hygiene 38:732-749

Paterson WD, Stewart JE (1974) In vitro phagocytosis by hemocytes of the American lobster (Homarus americanus). J Fish Res Board Can 31:1051-1056

Rittenburg HJ (1981) Gaffkemia infection and immunity in the American lobster (Homarus americanus). PhD thesis, University of Maine, Orono

Sindermann CJ (1990) Principal diseases of marine fish and shellfish, Vol 2. Diseases of marine shellfish, 2nd edn. Academic Press, New York, p 53-60, 281-288, 391-393

Sindermann CJ, Lightner DV (eds) (1988) Disease diagnosis and control in North American marine aquaculture, 2nd edn. Elsevier, Amsterdam, p 232-235

Sparks AK (1981) Bacterial diseases of invertebrates other than insects. In: Davidson EW (ed) Pathogenesis of invertebrate microbial diseases. Allanheld, Osmun, Totowa, NJ, p 323-363

Stewart JE (1984) Lobster diseases. Helgol Meeresunters 37: $243-254$

Stewart JE (1993) Infectious diseases of marine crustaceans. In: Couch JA, Fournie JW (eds) Pathobiology of marine and estuarine organisms. Advances in Fisheries Science. CRC Press, Boca Raton, FL, p 319-342

Stewart JE, Arie B (1974) Effectiveness of vancomycin against gaffkemia, the bacterial disease of lobsters (genus Homarus). J Fish Res Board Can 31:1873-1879

Stewart JE, Rabin H (1970) Gaffkemia, a bacterial disease of lobsters (genus Homarus). In: Snieszko SF (ed) A symposium on diseases of fishes and shellfishes, special publication No 5. American Fisheries Society, Washington, DC, p 431-439

Stewart JE, Zwicker BM (1974a) Comparison of various vaccines for inducing resistance in the lobster Homarus americanus to the bacterial infection, gaffkemia. J Fish Res Board Can 31:1887-1892

Stewart JE, Zwicker BM (1974b) Induction of internal defense mechanisms of the lobster Homarus americanus. In: Cooper EL (ed) Contemporary topics in immunobiology, Vol 4. Invertebrate immunology. Plenum Press, New York, p 233-239

Stewart JE, Cornick JW, Spears DI, McLeese DW (1966) Incidence of Gaffkya homari in natural lobster (Homarus americanus) populations of the Atlantic region of Canada. J Fish Res Board Can 23:1325-1330

Stewart JE, Cornick JW, Dingle JR (1967) An electronic method for counting lobster (Homarus americanus, Milne Edwards) hemocytes and the influence of diet on hemocyte numbers and hemolymph proteins. Can J Zool 45: 291-304

Stewart JE, Dockrill A, Cornick JW (1969) Effectiveness of the integument and gastric fluid as barriers against transmission of Gaffkya homari in the lobster Homarus americanus. J Fish Res Board Can 26:1-14

Stewart JE, Cornick JW, Zwicker BM, Arie B (2004) Studies on the virulence of Aerococcus viridans (var.) homari; the causative agent of gaffkemia, a fatal disease of homarid lobsters. Dis Aquat Org 60:149-155

Submitted: May 31, 2004; Accepted: July 26, 2004

Proofs received from author(s): November 9, 2004 